\title{
A Study of Muslims' Perceptions of Zakat as a Tax Reduction in Malaysia and Indonesia
}

\author{
Aula Ahmad Hafidh Saiful Fikri \\ Yogyakarta State University, Yogyakarta, Indonesia \\ Sharifah Faigah Syed Alwi (Corresponding author) \\ Universiti Teknologi MARA, Malaysia \\ Fuadah Johari \\ Universiti Sains Islam Malaysia, Malaysia \\ Maimun Sholeh \\ Yogyakarta State University, Yogyakarta, Indonesia
}

Eko Suprayitno

UIN Maulana Malik Ibrahim, Malang, Indonesia

Ngadiyono

Yogyakarta State University, Yogyakarta, Indonesia

Received: Nov. 21, 2021 Accepted: Feb. 6, 2022 Online published: Feb. 17, 2022

doi:10.5296/jpag.v12i1.19217

URL: https://doi.org/10.5296/jpag.v12i1.19217

\begin{abstract}
The study of zakat and taxes is still a highly regarded topic, especially in relation to the public's perception of zakat as a tax reduction. The aim of this study is to examine the influencing factors towards the perception of Muslims on the zakat policy as a form of tax reduction based on an adopted research model. To assess the quality of the models and
\end{abstract}


hypothesis, the Partial Least Square (PLS) - Structure Equations Model (SEM) is used in this study. There is a total of 152 respondents involved in this study whereby the respondents are almost evenly divided between Malaysians and Indonesians. The Malaysian citizens are a total of 77 people $(50.7 \%)$ and the remaining 75 people $(49.3 \%)$ are Indonesian residents. Based on the SEM results of the formation factors in the test produced by the method of Exploratory Factor Analysis, it can be said that only the knowledge about tax, religiosity and satisfaction variables have a significant and positive influence or impact on the perception towards tax through zakat system. The results of this study can reduce the gap in perception and understanding among the Muslim community regarding the perception of Muslims towards tax breaks through the zakat system and will surely play an important role for countries, policy makers and zakat or tax institutions both in Malaysia and Indonesia as well as around the world in utilizing practices which can be considered highly and positively beneficial to the Muslim society.

Keywords: Zakat, Tax Reduction, Muslims' Perceptions

\section{Introduction}

Islamic philosophy centers its main goals around the interests of society rather than personal or group interests. Generally, western philosophy differs from Islamic philosophy in which it is based on self-interest and is individualistic, leaning more towards glorifying individual freedom and prioritizing individual ownership, or in another sense, communists who prioritize government ownership and empower the government to oppress the people (Taha, Adam, Ali $\&$ Ariff, 2017). Therefore, Islam establishes clear and firm rules to be implemented throughout times for the government to manage the country fairly and wisely in order to ultimately ensure the welfare of the people. One of the Islamic regulations that allows the government to obtain a source of funds to run the country is tax and zakat, which are two different entities with zakat being a religious responsibility. Since zakat property rightfully belongs to the poor and underprivileged, Muslims must adhere to the obligation of performing zakat. Hence, individuals who believe in the obligation to give zakat and are financially capable to do so, yet are reluctant to pay or fulfill these obligations, may be subjected to the interference by the government and have their zakat forcibly taken from them.

The management of zakat in Indonesia is regulated under Law Number 23 Year 2011 concerning Zakat Management and Government Regulation (PP) and Number 14 Year 2014 concerning Implementation of the Law on Zakat Management. These two regulations are structured as the basis for receiving and managing zakat to act as a well-organized source of guidance for the benefit of the people. In Malaysia, the State Islamic Regional Councils (SIRCs) are the respective authoritative bodies to manage zakat collection and promote the solidity of socioeconomics (Razimi, Romle \& Erdris, 2016). As such, zakat collection and distribution in Malaysia are managed by zakat authorities at the states level. In 2019, RM 2,729 million zakat were collected for that year alone (Kassim, Abdullah Othman \& Haron, 2021). With the existence of the zakat institution, it serves as a place for a Muslim to directly hand over the distribution affairs of his zakat. However, evidently, a person would not be simply entrusting his/her zakat distribution without formerly acquiring information on the amil zakat institution 
in question and its advantages. It would only be natural for one to seek out assurance, especially with matters related to one's assets and liabilities, thus the whole zakat distribution process and the absence of difficulty in its implementation largely affects the decision in choosing the amil institution to distribute one's zakat.

As a country with the biggest population, according to the World Bank (2021), where the total population had reached 273.5 million people in 2020, Indonesia has the potential to inhabit a very large number of zakat payers. This potential projected in Indonesia is influenced by the demographic transition which is increasingly dominated by the young productive generation and the development of the middle-class in the digital economic era. Currently, the number of middle-class people is around 52 million (World Bank, 2020) and this number will continue to increase, as supported by the results of a survey conducted by the McKinsey Global Institute (2012) stating that Indonesia has the potential to become a developed country (number 7) by 2030, and the number of the middle-class is estimated to reach 135 million people. The increase in the number of middle-class people will undoubtedly increase the potential value of zakat in Indonesia. Mapping the potential for zakat is a part of the pillars of the Indonesian zakat architecture, namely pillar III, concerning the national zakat institution which includes a system of collection, distribution, and utilization. Mapping the potential for zakat with a measurement model that considers the specific variables of a region is required to determine the number of potential zakat figures to be collected in a particular area due to the differences in potentials and resources in each region. By detailing and mapping potential zakat by area, it is hoped that it can help zakat institutions in collecting zakat funds effectively and efficiently.

Indonesia is a country with the largest Muslim population in the world and has a huge potential for zakat. Asfarina, Ascarya and Beik (2019) reveal that the potential zakat amount is IDR 69.57 trillion, or equivalent to $0.56 \%$ of GDP under the optimistic scenario, as well as IDR 13.26 trillion, or equivalent to $0.11 \%$ of GDP. If every muzakki (person who is obliged to pay zakat) realizes and makes zakat payments, then the Islamic redistribution fund will be able to assist the government in alleviating poverty and the welfare of society. The large potential of zakat has not been optimally realized. Referring to the data released by BAZNAS, zakat collection is predicted to reach 12.19 - 13.22 Trillion Rupiahs with a moderate scenario where its growth is 20-30 percent in 2020 (Puskas BAZNAS, 2020).

Based on the results of the Indikator Pemetaan Potensi Zakat (IPPZ) study, it is shown that the Potential of Zakat in Indonesia in 2019 reached 233.8 Trillion Rupiahs. In this case, the zakat on income indicator had the highest potential value of zakat of 139.07 Trillion Rupiahs, which is then followed by zakat on deposits of 58.76 Trillion Rupiahs, zakat on agricultural products of 19.79 Trillion Rupiahs and zakat on livestock of 9.51 Trillion Rupiahs (Puskas BAZNAS, 2020).

The low realization of Zakat Infaq and Sodaqoh (ZIS) revenue is due to the low level of compliance, awareness and public trust in paying ZIS through zakat institutions (Abdullah \& Sapiei, 2018; Farah, Shafiai \& Ismail, 2019). Individual motivation to pay ZIS through the amil (collector and distributor) zakat institution is influenced by the level of religiosity (Abdullah \& 


\section{Macrothink}

Journal of Public Administration and Governance

ISSN 2161-7104

2022, Vol. 12, No. 1

Sapiei, 2018; Farah et al., 2019; Ma'fiyah, Yughi \& Awaludin, 2018). The results from a research conducted by Abdullah and Sapiei (2018) show that religiosity had a significant influence on zakat compliance. From various kinds of literature studies, this study aims to focus more on factors which will influence the perception of Muslims on the zakat policy as a tax reduction based on an adopted research model. This will have policy implications that can help zakat and tax authorities in Malaysia and Indonesia to take corrective actions to adjust or improve current policies on zakat and taxes based on the perceptions of Muslim consumers. The results of this study can reduce the gap in perception and understanding among the Muslim community regarding the perception of Muslims towards tax breaks through the zakat system in Malaysia and Indonesia. Research in this area is still very sparse, thus the results of this study play an important role for countries, policy makers and zakat or tax institutions both in Indonesia and Malaysia as well as around the world in utilizing practices that are considered highly positive.

\section{Method}

\subsection{Data}

The scope of this study involves the Muslim communities in Malaysia and Indonesia who already have sources of income. The variables used in this study are the variables of knowledge of zakat (KZ), knowledge of taxes (KT), halal and haram aspects (HHA), religiosity $(\mathrm{R})$, legal aspects and trust $(\mathrm{T})$, satisfaction $(\mathrm{S})$ and motivation $(\mathrm{M})$ as the independent variables, and the perception towards tax through zakat system (PTZS) as the dependent variable. The technique used is probability sampling technique. The sample size for the Structural Equation Model with estimation procedures generally uses Maximum likelihood estimation (MLE).

\subsection{Model Development}

Operational variables can provide an overview of the variables used in research so that it can be measured and analyzed in accordance with the research objectives. According to Juliansyah Noor (2017), in Structure Equations Model (SEM), independent variables are also referred to as exogenous variables, and the dependent variable is called an endogenous variable. Table 1 below shows the operational variables used for this research and their indicators.

Table 1. Operational Variables

\begin{tabular}{|l|l|l|}
\hline No & Variables & Indicators \\
\hline 1 & $\begin{array}{l}\text { Knowledge about } \\
\text { Zakat } \\
(\mathbf{K Z )}\end{array}$ & Zakat on income is a religious obligation \\
\cline { 3 - 4 } & $\begin{array}{l}\text { The minimum amount which is applicable for zakat in } \\
\text { Islam }\end{array}$ \\
& $\begin{array}{l}\text { Zakat is a social obligation towards Muslim ummah } \\
\text { (nation) }\end{array}$ \\
\hline
\end{tabular}




\begin{tabular}{|c|c|c|}
\hline & & Pay $2.5 \%$ of my wealth if zakat is applicable for me \\
\hline & & $\begin{array}{l}\text { With zakat, I believe that the economic condition of the } \\
\text { Muslim ummah will be improved }\end{array}$ \\
\hline \multirow[t]{4}{*}{2} & \multirow{4}{*}{$\begin{array}{l}\text { Knowledge about } \\
\text { Tax } \\
\text { (KT) }\end{array}$} & $\begin{array}{l}\text { The minimum amount of money for which I have to pay } \\
\text { tax to the government }\end{array}$ \\
\hline & & $\begin{array}{l}\text { Knowledge about the tax rates }(\%) \text { according to the } \\
\text { Malaysian Income Tax Act/Indonesian Income Tax Act }\end{array}$ \\
\hline & & $\begin{array}{l}\text { Institutions are providing proper information to motivate } \\
\text { the Muslim consumers about this system }\end{array}$ \\
\hline & & $\begin{array}{l}\text { The tax authority is providing proper information to } \\
\text { motivate the Muslim consumers about this system }\end{array}$ \\
\hline \multirow[t]{6}{*}{3} & \multirow{6}{*}{$\begin{array}{l}\text { Halal and Haram } \\
\text { Aspect } \\
\text { (A) }\end{array}$} & $\begin{array}{l}\text { Strict regarding halal and haram aspects of Islamic Law } \\
\text { or Shariah law }\end{array}$ \\
\hline & & $\begin{array}{l}\text { Ask my friends or scholars about its permissibility in } \\
\text { Islam if I am not clear about anything }\end{array}$ \\
\hline & & $\begin{array}{l}\text { Enjoying tax rebate through payment of zakat is } \\
\text { permissible (halal) in Islam }\end{array}$ \\
\hline & & $\begin{array}{l}\text { Enjoying tax rebate through zakat while I am paying my } \\
\text { tax because I feel it is permitted (halal) }\end{array}$ \\
\hline & & Fulfill the requirements of paying zakat \\
\hline & & Follow Islamic guidelines to lead my life \\
\hline \multirow[t]{5}{*}{4} & \multirow[t]{5}{*}{ Religiosity (R) } & $\begin{array}{l}\text { My religious beliefs influence me to get the advantage of } \\
\text { the tax rebate through charity }\end{array}$ \\
\hline & & $\begin{array}{l}\text { Maintain legal obligations related to tax because I feel it } \\
\text { protects my social image }\end{array}$ \\
\hline & & $\begin{array}{l}\text { Enjoying tax rebate through zakat is a good system for } \\
\text { Muslims }\end{array}$ \\
\hline & & $\begin{array}{l}\text { Tax rebate through the zakat system is a sign of religious } \\
\text { duty towards the Muslims }\end{array}$ \\
\hline & & $\begin{array}{l}\text { Religious lectures enhance understanding to choose this } \\
\text { system easily without hesitation }\end{array}$ \\
\hline
\end{tabular}




\begin{tabular}{|c|c|c|}
\hline & & $\begin{array}{l}\text { The information of religious books and magazines } \\
\text { influence me to enjoy tax rebate through zakat }\end{array}$ \\
\hline & & $\begin{array}{l}\text { Motivate others to enjoy tax rebate through zakat as their } \\
\text { rights to be free from double taxation }\end{array}$ \\
\hline \multirow[t]{14}{*}{5} & \multirow{14}{*}{$\begin{array}{l}\text { Legal Aspect and } \\
\text { Trust } \\
\text { (T) }\end{array}$} & $\begin{array}{l}\text { Paying tax to follow the government rules and regulations } \\
\text { as a citizen or resident }\end{array}$ \\
\hline & & $\begin{array}{l}\text { Follow the government rules and regulations while I pay } \\
\text { my tax }\end{array}$ \\
\hline & & Tax is an order from the government \\
\hline & & Tax is legally conscious \\
\hline & & $\begin{array}{l}\text { Tax is a compulsory payment because it is imposed by the } \\
\text { government }\end{array}$ \\
\hline & & $\begin{array}{l}\text { Tax contributes in the poverty reduction, social and } \\
\text { economic development of the country, social and } \\
\text { economic development of the ummah }\end{array}$ \\
\hline & & Zakat institution can be trusted with zakat funds \\
\hline & & $\begin{array}{l}\text { Zakat institution has delivered zakat funds to the right } \\
\text { recipients. }\end{array}$ \\
\hline & & Zakat institution has high credibility \\
\hline & & Zakat institution is trusted by society \\
\hline & & I believe in zakat institution \\
\hline & & Zakat institution has been transparent in financing \\
\hline & & $\begin{array}{l}\text { Zakat institution officer has knowledge, experience, and } \\
\text { competence about zakat }\end{array}$ \\
\hline & & $\begin{array}{l}\text { Zakat institution officer can manage zakat fund well } \\
\text { Zakat institution officers can manage zakat funds }\end{array}$ \\
\hline \multirow[t]{3}{*}{6} & \multirow[t]{3}{*}{ Satisfaction (S) } & $\begin{array}{l}\text { Zakat reception procedure of zakat institution is quick } \\
\text { and good }\end{array}$ \\
\hline & & Zakat disbursement procedure is on the right target \\
\hline & & Zakat officer gives charity information responsively \\
\hline
\end{tabular}




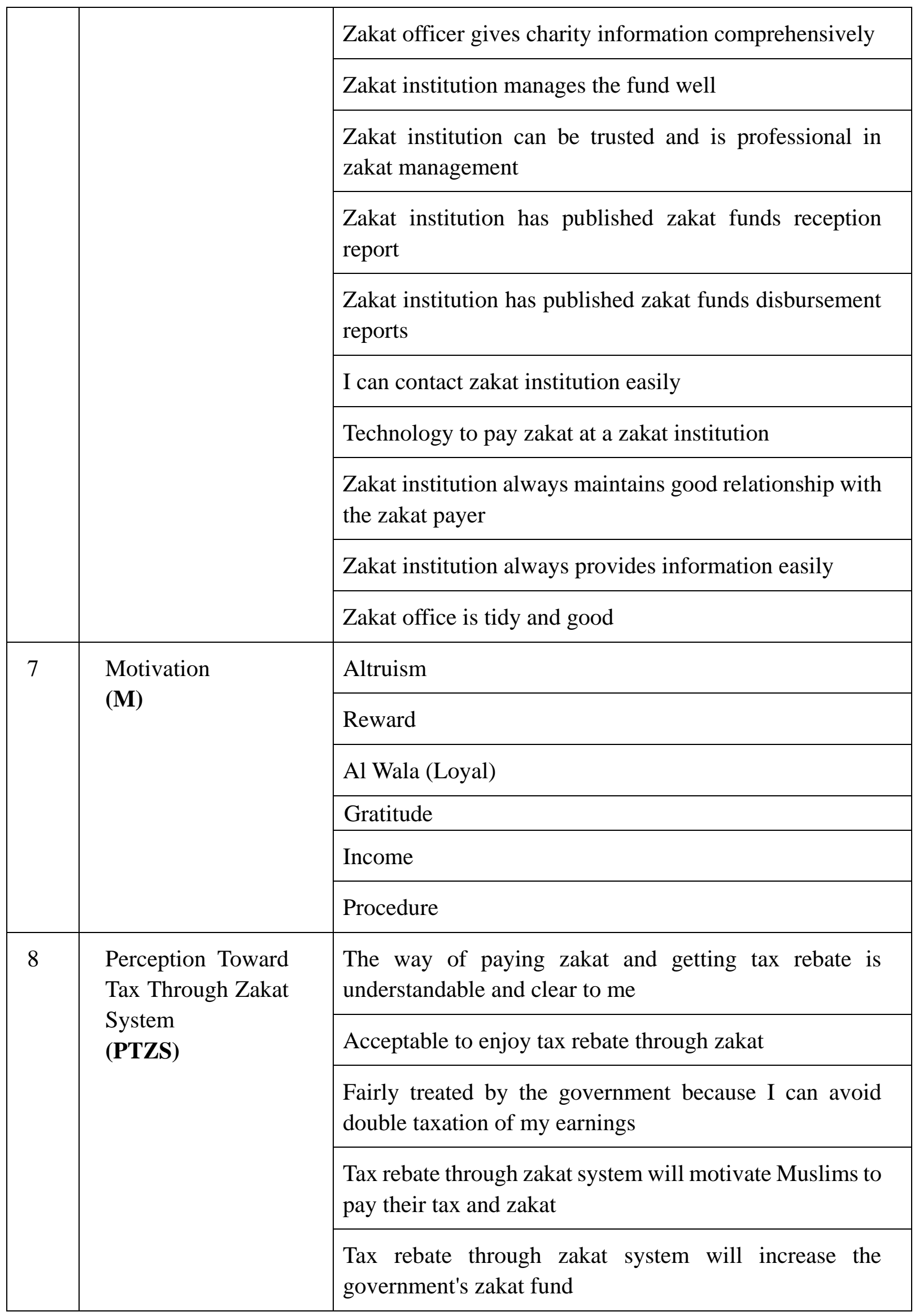




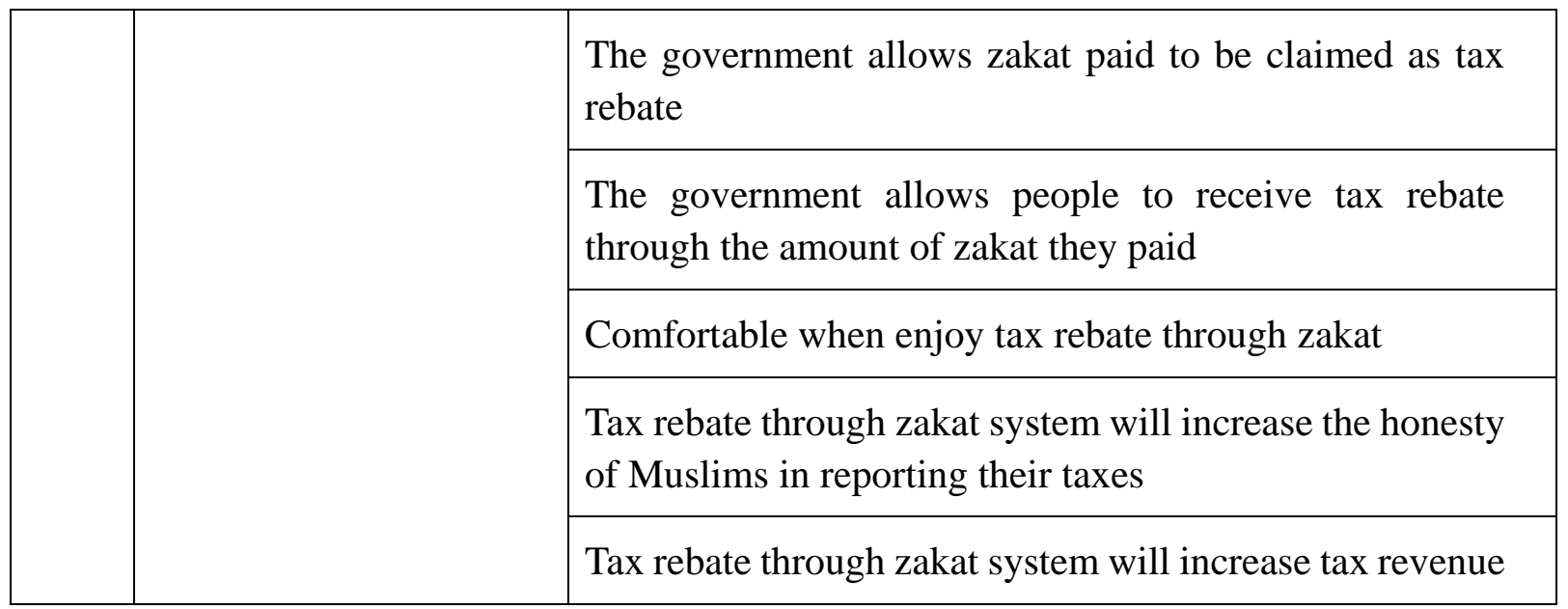

This study uses a unidimensional construct with reflective indicators. The unidimensional construct according to Ghozali and Latan (2015) is a construct that is formed directly from the manifest variable with the direction of the indicator being either reflexive or formative. Meanwhile, the construct with reflexive indicators assumes that the covariance between the model measurements is explained by the variant which is the manifestation of the construct domain. Based on this explanation, this adopted research model can be described in Figure 1 as follows:

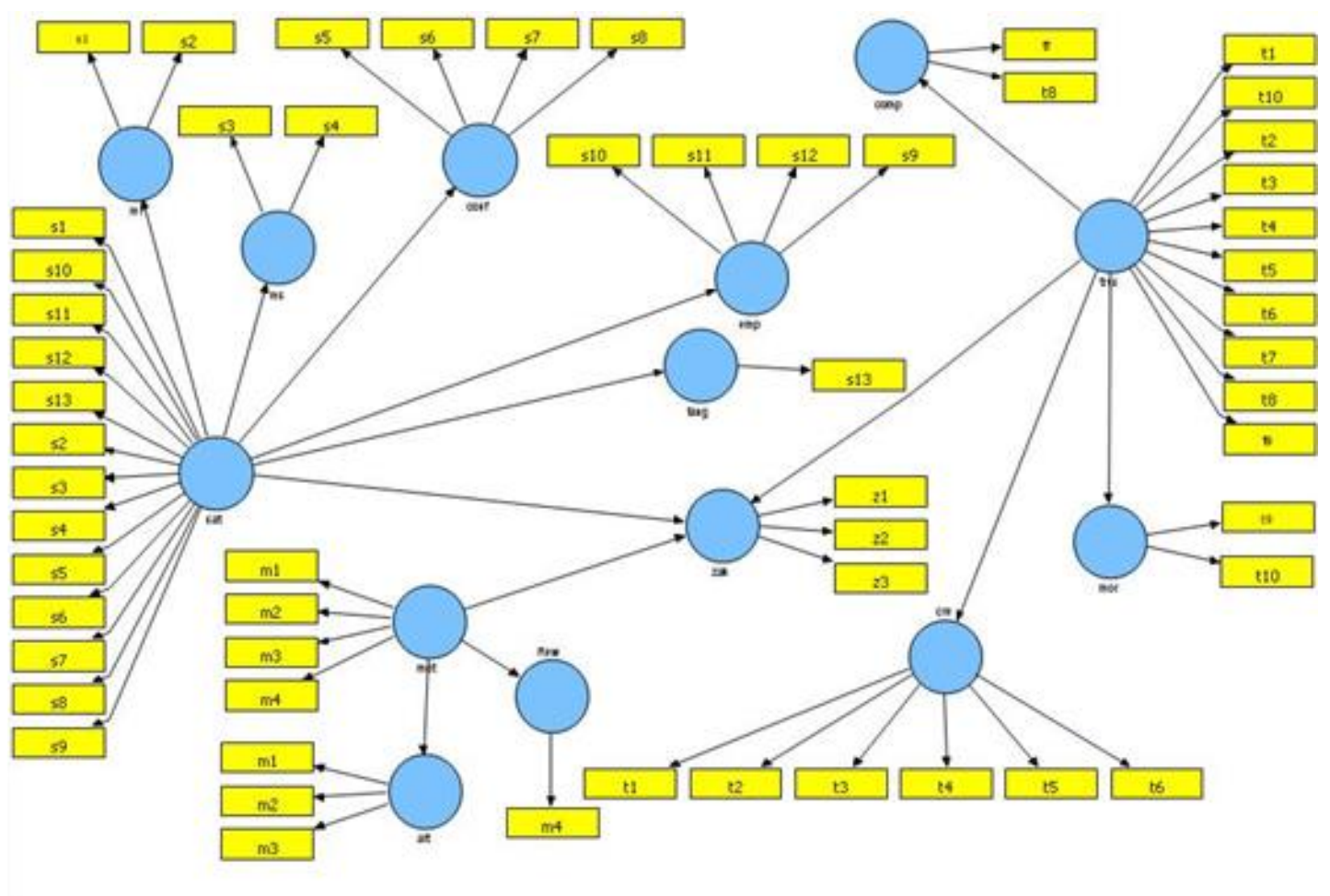

Figure 1. Research Model

\subsection{Method}

According to Juliansyah Noor (2017), data analysis techniques are a way of analyzing research 
data, including statistical tools that are relevant for use in research. The method used in data analysis and hypothesis testing in this study is by using the method Structural Equation Model - Partial Least Square (SEM-PLS). SEM is a statistical technique used to build and test statistical models which are usually in the form of causal models. SEM is able to explain the relationship of variables in a complex manner and as well as the direct or indirect effects of one or more variables on other variables. SEM prioritizes confirmatory modeling rather than exploratory modeling so it is more appropriate to use for theory testing (quantitative studies) than theory development (quantitative studies). Basically, PLS is developed to test weak theories and weak data such as small sample sizes or data normality problems. Although PLS is used to explain whether there is a relationship between latent variables, it can also be used to confirm the theory. Meanwhile, PLS is a variant-based structural equation analysis which can simultaneously perform measurement model testing as well as structural model testing. The measurement model is used for the validity test and the reality test, while the structural model is used for the causality test (hypothesis testing with predictive models).

\section{Results}

\subsection{Descriptive Statistics}

This study uses three technical stages of comprehensive analysis through demographic description of respondents based on Distribution Frequency, followed by factor testing which is carried out using Exploratory Factor Analysis (EFA) to select and determine the number of factors and related items, then in the final stage, data analysis is carried out in the form of modeling technique.

For the first stage, in Table 2 for Distribution Frequency below, it is known that of the 152 respondents who are sampled in this study, as many as 60 people $(39.5 \%)$ are female and 92 $(60.5 \%)$ are male. In addition, the majority of respondents are Malaysian citizens with 77 people $(50.7 \%)$ and the remaining 75 people $(49.3 \%)$ are Indonesian residents. Moreover, there are 51 respondents (33.6\%) aged 17-29 years, 44 respondents (28.9\%) aged 30-39 years, another 55 respondents $(35.5 \%)$ aged $40-58$ years and the remaining 3 respondents $(2 \%)$ are aged $>58$ years.

Furthermore, based on the aspect of education, it shows that there are 11 respondents $(7.2 \%)$ who have High School educational background, Diploma as many as 4 respondents $(2.6 \%)$, Bachelor as many as 58 respondents (38.2\%), Masters as many as 68 respondents $(44.7 \%)$ and Doctorate as many as 11 respondents (7.2\%). Meanwhile, based on the job profile, the majority of the respondents are private workers and civil servants with 62 people (40.8\%) and 69 people (45.4\%) respectively, whereas 20 respondents $(13.2 \%)$ are entrepreneurs and only 1 respondent $(0.7 \%)$ works as a legal officer. It can also be seen that the majority of respondents has an income of $<\$ 170$ for 31 people $(20.4 \%), \$ 170-\$ 230$ for 8 people $(5.3 \%), \$ 230$ - \$ 350 for 24 people (15.8) and > \$350 for 89 people $(58.6 \%)$. 
Table 2. Distribution Frequency

\begin{tabular}{|c|c|c|c|c|c|}
\hline \multicolumn{2}{|c|}{ Indicators } & \multirow{2}{*}{$\begin{array}{c}\text { Frequency } \\
60\end{array}$} & \multirow{2}{*}{$\begin{array}{c}\text { Percent } \\
39.5\end{array}$} & \multirow{2}{*}{$\begin{array}{c}\text { Valid } \\
\text { Percent } \\
39.5\end{array}$} & \multirow{2}{*}{$\begin{array}{c}\text { Cumulative } \\
\text { Percent } \\
39.5\end{array}$} \\
\hline Gender & Woman & & & & \\
\hline & Men & 92 & 60.5 & 60.5 & 100.0 \\
\hline & Total & 152 & 100.0 & 100.0 & \\
\hline \multirow[t]{3}{*}{ Citizens } & Malaysia & 77 & 50.7 & 50.7 & 50.7 \\
\hline & Indonesia & 75 & 49.3 & 49.3 & 100.0 \\
\hline & Total & 152 & 100.0 & 100.0 & \\
\hline \multirow[t]{5}{*}{ Ages } & 17 - 29 years & 51 & 33.6 & 33.6 & 33.6 \\
\hline & 30 - 39 years & 44 & 28.9 & 28.9 & 62.5 \\
\hline & $40-58$ years & 54 & 35.5 & 35.5 & 98.0 \\
\hline & $>58$ years & 3 & 2.0 & 2.0 & 100.0 \\
\hline & Total & 152 & 100.0 & 100.0 & \\
\hline \multirow[t]{6}{*}{ Education } & High school & 11 & 7.2 & 7.2 & 7.2 \\
\hline & Diploma & 4 & 2.6 & 2.6 & 9.9 \\
\hline & Bachelor & 58 & 38.2 & 38.2 & 48.0 \\
\hline & Masters & 68 & 44.7 & 44.7 & 92.8 \\
\hline & Doctorate & 11 & 7.2 & 7.2 & 100.0 \\
\hline & Total & 152 & 100.0 & 100.0 & \\
\hline \multirow[t]{5}{*}{ Job } & Private & 62 & 40.8 & 40.8 & 40.8 \\
\hline & Civil & 69 & 45.4 & 45.4 & 86.2 \\
\hline & Entrepreneur & 20 & 13.2 & 13.2 & 99.3 \\
\hline & Apparatus & 1 & .7 & .7 & 100.0 \\
\hline & Total & 152 & 100.0 & 100.0 & \\
\hline \multirow[t]{5}{*}{ Income } & $<\$ 170$ & 31 & 20.4 & 20.4 & 20.4 \\
\hline & $\$ 170-\$ 230$ & 8 & 5.3 & 5.3 & 25.7 \\
\hline & $\$ 230-\$ 350$ & 24 & 15.8 & 15.8 & 41.4 \\
\hline & $>\$ 350$ & 89 & 58.6 & 58.6 & 100.0 \\
\hline & Total & 152 & 100.0 & 100.0 & \\
\hline
\end{tabular}

Source: SPSS Data process

\subsection{Results}

In the second stage, SEM testing is carried out on the factors that form Perception towards Tax through Zakat System produced by the method of EFA with the aim of measuring the constructs of the relationship between the manifest and latent variables and analyzing the relationship between variables based on the results of mathematical representation (Danks, Sharma, \& Sarstedt, 2020; Memon \& Rahman, 2014). 
Table 3. Discriminant Validity of Outer Loading

\begin{tabular}{|c|c|c|c|c|c|c|c|c|}
\hline Indicator & KT & $\mathrm{KZ}$ & $\mathbf{M}$ & PTZS & $\mathbf{R}$ & $\mathbf{S}$ & $\mathbf{T}$ & $\mathbf{V}$ \\
\hline KT1 & 0.952 & & & & & & & \\
\hline KT2 & 0.820 & & & & & & & \\
\hline KZ1 & & 0.735 & & & & & & \\
\hline KZ2 & & 0.714 & & & & & & \\
\hline KZ3 & & 0.841 & & & & & & \\
\hline KZ4 & & 0.784 & & & & & & \\
\hline M1 & & & 0.854 & & & & & \\
\hline M2 & & & 0.882 & & & & & \\
\hline M3 & & & 0.897 & & & & & \\
\hline M4 & & & 0.819 & & & & & \\
\hline PTZS1 & & & & 0.746 & & & & \\
\hline PTZS10 & & & & 0.860 & & & & \\
\hline PTZS2 & & & & 0.783 & & & & \\
\hline PTZS3 & & & & 0.882 & & & & \\
\hline PTZS4 & & & & 0.863 & & & & \\
\hline PTZS5 & & & & 0.857 & & & & \\
\hline PTZS6 & & & & 0.791 & & & & \\
\hline PTZS7 & & & & 0.841 & & & & \\
\hline PTZS8 & & & & 0.848 & & & & \\
\hline PTZS9 & & & & 0.890 & & & & \\
\hline R1 & & & & & 0.719 & & & \\
\hline $\mathbf{R 2}$ & & & & & 0.753 & & & \\
\hline R3 & & & & & 0.885 & & & \\
\hline R4 & & & & & 0.888 & & & \\
\hline R5 & & & & & 0.832 & & & \\
\hline R6 & & & & & 0.841 & & & \\
\hline S1 & & & & & & 0.924 & & \\
\hline S2 & & & & & & 0.962 & & \\
\hline T1 & & & & & & & 0.824 & \\
\hline T10 & & & & & & & 0.897 & \\
\hline T11 & & & & & & & 0.792 & \\
\hline T12 & & & & & & & 0.774 & \\
\hline T13 & & & & & & & 0.902 & \\
\hline T14 & & & & & & & 0.903 & \\
\hline T15 & & & & & & & 0.853 & \\
\hline T16 & & & & & & & 0.858 & \\
\hline T17 & & & & & & & 0.701 & \\
\hline T2 & & & & & & & 0.843 & \\
\hline T3 & & & & & & & 0.874 & \\
\hline T4 & & & & & & & 0.888 & \\
\hline T5 & & & & & & & 0.843 & \\
\hline T6 & & & & & & & 0.884 & \\
\hline T7 & & & & & & & 0.821 & \\
\hline T8 & & & & & & & 0.867 & \\
\hline T9 & & & & & & & 0.846 & \\
\hline A1 & & & & & & & & 1.00 \\
\hline
\end{tabular}

Table 3 above shows that the results of outer loading on the form explanatory factor analysis are displaying all indicators used in this test are above the threshold value of 0.7 (Farrell \& Rudd, 2009), which would mean that all items on the indicators are valid and can be used for 
testing the next stage. Subsequently, to ensure the quality of the data in this study, a discriminant validity test was carried out through the Fornell-Larcker Criterion with a threshold of 0.7 on variable correlation in Table 44 (Ab Hamid, Sami \& Mohmad Sidek, 2017; Henseler, Ringle, \& Sarstedt, 2014) as follows:

Table 4. Discriminant Test

\begin{tabular}{ccccccccc}
\hline Indicator & KT & KZ & M & PTZS & R & S & T & A \\
\hline KT & 0.889 & & & & & & & \\
\hline KZ & 0.140 & 0.770 & & & & & & \\
\hline M & 0.201 & 0.593 & 0.863 & & & & & \\
\hline PTZS & 0.403 & 0.417 & 0.471 & 0.837 & & & & \\
\hline $\mathbf{R}$ & 0.295 & 0.456 & 0.397 & 0.741 & 0.822 & & & \\
\hline S & 0.316 & 0.356 & 0.468 & 0.551 & 0.359 & 0.943 & & \\
\hline T & 0.411 & 0.248 & 0.458 & 0.534 & 0.450 & 0.759 & 0.847 & \\
\hline $\mathbf{A}$ & 0.262 & 0.251 & 0.254 & 0.469 & 0.532 & 0.267 & 0.308 & 1.000 \\
\hline
\end{tabular}

Table 4 above shows that all indicators in this test have a Fornell-Larcker Criterion value above the threshold value of 0.7 with KT (0.889), KZ (0.770), M (0.863), PTZS (0.837), R (0.822), HHA (0.883), S (0.943), T (0.847) and A (1.000). As such, it can be continued in reliability testing through the Cronbach's Alpha value of 0.7, Composite Reliability of 0.7 and Average Variance Extracted (AVE) of 0.5 (Ab Hamid et al., 2017; Chan \& Lay, 2018; Cheah, Sarstedt, Ringle, Ramayah, \& Ting, 2018).

Table 5 shows that all indicators used in this study have a value higher than the threshold for reliability testing based on Cronbach's Alpha, Composite Reliability and AVE, indicating that each indicator is considered to have met the validity of measuring items in forming latent variables (Roni, Djajadikerta \& Ahmad, 2015).

Table 5. Reliability Test

\begin{tabular}{|c|c|c|c|}
\hline Indicators & Cronbach's Alpha & Composite Reliability & $\begin{array}{c}\text { Average } \\
\text { Variance } \\
\text { Extracted (AVE) }\end{array}$ \\
\hline KT & 0.755 & 0.882 & 0.790 \\
\hline KZ & 0.776 & 0.853 & 0.593 \\
\hline M & 0.892 & 0.921 & 0.746 \\
\hline PTZS & 0.952 & 0.959 & 0.701 \\
\hline R & 0.903 & 0.926 & 0.676 \\
\hline S & 0.879 & 0.941 & 0.889 \\
\hline T & 0.975 & 0.977 & 0.717 \\
\hline $\mathbf{A}$ & 1.000 & 1.000 & 1.000 \\
\hline
\end{tabular}

Later in the final stage, testing is carried out between the variables of the exploratory factor analysis formation against the Perception towards Tax through Zakat System variable, 


\section{Macrothink}

through the path coefficient in Figure 2 as follows:

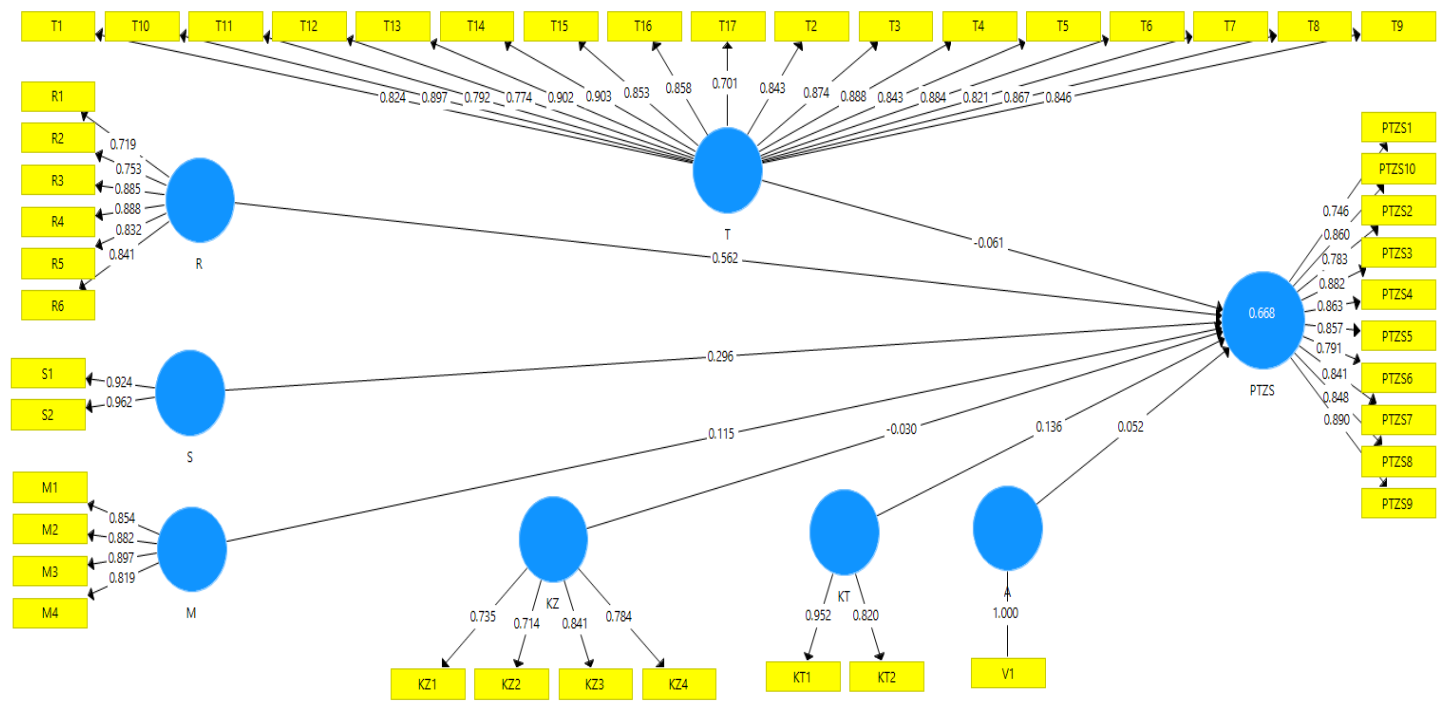

Figure 2. Result of Structure Equations Model (SEM)

The test results in table 6 shows that the relationship between knowledge about tax (KT) and Perception Towards Tax Through Zakat System (PTZS) has a path coefficient level of 0.136 with a significance of 0.036, implying that KT has a positive influence on PTZS. Palil (2005) states that knowledge of taxes is the most important part of achieving tax optimization, while having a good understanding of the rules and functions of tax is predicted to be able to encourage an increase in income in the tax sector, so as to create better welfare for the community (Al-Mamun \& Haque, 2015; Al-Mamun, Haque \& Jan, 2019; Djatmiko, 2019). Based on the test results, knowledge about zakat (KZ) has an efficiency value of -0.030 with a significance level of 0.694, indicating no significant relationship between $\mathrm{KZ}$ and PTZS. This is because there are still some aspects lacking in zakat regulation limiting the optimization of zakat, as a good understanding without the support of clear regulations can affect the Perception towards the Tax through Zakat System (Saad \& Foori, 2020).

Table 6. Path Coefficient and R Square

\begin{tabular}{ccccccc}
\hline & $\begin{array}{c}\text { Original } \\
\text { Sample } \\
(\mathbf{O})\end{array}$ & $\begin{array}{c}\text { Sample } \\
\text { Mean } \\
(\mathbf{M})\end{array}$ & $\begin{array}{c}\text { Standard } \\
\text { Deviation } \\
(\text { STDEV })\end{array}$ & $\begin{array}{c}\text { T Statistics } \\
(|\mathbf{O} / \mathbf{S T D E}|)\end{array}$ & P Values & Note \\
\hline $\begin{array}{c}\text { KT }-> \\
\text { PTZS }\end{array}$ & 0.136 & 0.147 & 0.065 & 2.103 & $\mathbf{0 . 0 3 6 *}$ & Support \\
\hline KZ $->$ & -0.030 & -0.004 & 0.077 & 0.394 & $\mathbf{0 . 6 9 4}$ & $\begin{array}{c}\text { Not } \\
\text { PTZS }\end{array}$ \\
\hline $\begin{array}{c}\text { M }-> \\
\text { PTZS }\end{array}$ & 0.115 & 0.121 & 0.060 & 1.905 & $\mathbf{0 . 0 5 7}$ & $\begin{array}{c}\text { Not } \\
\text { Support }\end{array}$ \\
\hline $\begin{array}{c}\text { R -> } \\
\text { PTZS }\end{array}$ & 0.562 & 0.552 & 0.072 & 7.789 & $\mathbf{0 . 0 0 0 *}$ & Support \\
\hline
\end{tabular}




\section{$\Lambda$ Macrothink}

Journal of Public Administration and Governance ISSN 2161-7104

\begin{tabular}{ccccccc}
\hline S -> PTZS & 0.296 & 0.281 & 0.084 & 3.517 & $\mathbf{0 . 0 0 0 *}$ & Support \\
\hline $\begin{array}{c}\text { T }-> \\
\text { PTZS }\end{array}$ & -0.061 & -0.055 & 0.095 & 0.649 & $\mathbf{0 . 5 1 7}$ & $\begin{array}{c}\text { Not } \\
\text { Support }\end{array}$ \\
\hline $\begin{array}{c}\text { A -> } \\
\text { PTZS }\end{array}$ & 0.052 & 0.050 & 0.066 & 0.796 & $\mathbf{0 . 4 2 6}$ & $\begin{array}{c}\text { Not } \\
\text { Support }\end{array}$ \\
\hline $\begin{array}{c}\text { R Square } \\
\text { of PTZS }\end{array}$ & & $\mathbf{0 . 6 6 8}$ & & & \\
\hline $\begin{array}{c}\text { R Square } \\
\text { Adjusted } \\
\text { of PTZS }\end{array}$ & & $\mathbf{0 . 6 5 2}$ & & & \\
\hline
\end{tabular}

The testing on the relationship between motivation (M) and PTZS shows the level of $\mathrm{M}$ coefficient of 0.115 with a significance of 0.057 , denoting that there is no significant relationship and influence between the two variables. Nurhayati and Siswantoro (2015) state that motivation basically does not have a significant effect on the PTZS. This is because zakat is positioned as a tax cutter which has an impact on reducing government revenue. In addition, people paying taxes is something that must be done even if there is no reduction in taxes (Abu Bakar \& Rashid, 2010).

The results of the analysis of the influence of religiosity (R) on PTZS show that there is a coefficient value of 0.562 with a significance of 0.000 in the variable $R$, implying that there is a positive relationship and significant on the variable R on PTZS. Djatmiko (2019) states that zakat is a religious obligation for Muslims, thus it becomes binding because religiosity plays a role in influencing individual moral decisions through the commitment to carrying out religious orders (Adachi, 2018). The results of the analysis on the satisfaction (S) relationship to PTZS show a coefficient value of 0.296 with a significance level of 0.000 , hence the variable $\mathrm{S}$ is able to provide a positive and significant influence on PTZS. Al-Mamun et al. (2019) explain that the zakat performance of an institution is highly dependent on the quality of the satisfaction on the services provided, therefore it is important for the institution to provide the best service in order to increase optimization in the zakat and tax sector (Zainal, Bakar \& Saad, 2016).

The test results show that the legal aspect and trust $(\mathrm{T})$ variable has a coefficient value of -0.061 with a significance value of 0.517 , indicating that there is no significant relationship between the T variable and PTZS. Fauziati, Minovia, Muslim and Nasrah (2016) state that trust does not provide a significant effect as a reinforcement in the relationship of knowledge about taxes on tax payments, but it provides a good reputation in tax management so that it can influence perception towards tax through zakat system (Sani Adamu \& Ram Al Jaffri, 2016). The testing on variable halal and haram aspect (A) on PTZS shows a coefficient value of 0.052 with a significance of 0.426 , showing that there is no significant influence between the two variables, hence A cannot affect PTZS, primarily due to the obligation to give zakat is not considered as an essential aspect of religious compliance. Consequently, most individuals often think that the wealth they acquire is the result of their hard work, especially private sector workers (Anwar \& Arifin, 2018). 
In the results of the feasibility test of the model, the determinant coefficient value (R Square) was 0.668, signifying that the model used in the PTZS measurement was categorized as good. In addition, through the value of $\mathrm{R}$ Square, it can be said that the model used in this study can explain the construct for the PTZS variable by $66.8 \%$ and the rest is explained by other variables not included in this research model.

\section{Discussion}

\subsection{Conclusion}

This study aims to examine the factors influencing Muslims' perception of taxes through the zakat system based on the adopted model. Based on the results of the Distribution Frequency, it can be stated that based on the aspects of Gender, Citizens, Age, Education, Job, and Income, the majority of respondents in this study were male (60.5\%), Malaysian nationality (50.7\%), aged 40 - 58 years (35.5\%), educated at Masters level (44.7\%), and working as a government employee (45.4\%) with an income of $>\$ 350(58.6 \%)$. The results of the test are EFA based on the adoption of the perception towards tax through zakat system model through knowledge about zakat, knowledge about tax, halal haram aspect, religiosity, legal aspect and trust, satisfaction and motivation which experienced changes after the identification process on latent variables and internal attributes, thus forming the variables of trust, religiosity, satisfaction, motivation, knowledge about zakat, knowledge about tax, and awareness as factors that determine perception towards tax through zakat system. At the testing stage of the model through SEM based on the results of the formation factors in the test, it can be said that only the knowledge about tax, religious and satisfaction variables have an impact on perception towards tax through zakat system positively and significantly, but through testing the service ability of a model results in a determinant coefficient (R Square) of 0.668 , meaning that the model used in the PTZS measurement is in a good category.

\subsection{Recommendation}

The recommendation of this study is to encourage the government to promote the increase in taxpayer numbers, because without a taxpayer number, the government will find it difficult to optimize the tax reduction program through zakat. In addition, the government must guarantee legal certainty in determining zakat as a tax cut. Furthermore, the government can collaborate with religious leaders in socializing the program, so that literacy in tax reduction programs through zakat can be known to the whole community. Additionally, in order to optimize the program, it should be carried out under the supervision and coordination of the Ministry of Finance and the Ministry of Religion, enabling the performance of the institution to run optimally. The use of zakat funds and how they are distributed by the zakat institution under the government should be examined in the future to give the Muslim community more trust in continuing to pay zakat.

\section{References}

Ab Hamid, M. R., Sami, W., \& Mohmad Sidek, M. H. (2017). Discriminant validity assessment: Use of Fornell \& Larcker criterion versus HTMT criterion. Journal of Physics: Conference Series, 890(1). https://doi.org/10.1088/1742- 6596/890/1/012163 
Abdullah, M., \& Sapiei, N. S. (2018). Do religiosity, gender and educational background influence zakat compliance? The case of Malaysia. International Journal of Social Economics. https://doi.org/10.1108/IJSE-03-2017-0091

Abu Bakar, N. B., \& Rashid, H. M. A. (2010). Motivations of paying zakat on income: Evidence from Malaysia. International Journal of Economics and Finance. https://doi.org/10.5539/ijef.v2n3p76

Adachi, Mari, (2018),Discourses of institutionalization of zakat management system in contemporary Indonesia: Effect of the revitalization of Islamic economics. International Journal of Zakat, 3(1), 25-35.

Al-Mamun, A., \& Haque, A. (2015). Tax Reduction through zakat: An empirical investigation on Muslim in Malaysia. Share: Jurnal Ekonomi Dan Keuangan Islam, 4(2). https://doi.org/10.22373/share.v4i2.1027

Al-Mamun, A., Haque, A., \& Jan, M. T. (2019). Measuring perceptions of Muslim consumers toward income tax rebate over zakat on income in Malaysia. Journal of Islamic Marketing, 11(2), 368-392. https://doi.org/10.1108/JIMA-12-2016-0104

Anwar, A. Z., \& Arifin, M. (2018). The degree of understanding of zakat on profession/income in Jepara regency. Jurnal Ilmiah Al-Syir'ah, 16(2), 138. https://doi.org/10.30984/jis.v16i2.665

Asfarina, M., Ascarya, A., \& Beik, I. S. (2019). Re-estimating the zakat potential in Indonesia based on classical and contemporary fiqh approaches. Journal of Islamic Monetary Economics and Finance, 5(2). https://doi.org/10.21098/jimf.v5i2.1068

Chan, S. H., \& Lay, Y. F. (2018). Examining the reliability and validity of research instruments using partial least squares structural equation modeling (PLSSEM). Journal of Baltic Science Education, 17(2), 239-251.

Cheah, J. H., Sarstedt, M., Ringle, C. M., Ramayah, T., \& Ting, H. (2018). Convergent validity assessment of formatively measured constructs in PLSSEM: On using single-item versus multi-item measures in redundancy analyses. International Journal of Contemporary Hospitality Management, 30(11), 3192-3210. https://doi.org/10.1108/IJCHM-10-2017-0649

Danks, N. P., Sharma, P. N., \& Sarstedt, M. (2020). Model selection uncertainty and multimodel inference in partial least squares structural equation modeling (PLSSEM). Journal of Business Research, 113(March), 13-24. https://doi.org/10.1016/j.jbusres.2020.03.019

Djatmiko, H. (2019). Re-formulation zakat system as tax reduction in Indonesia. Indonesian $\begin{array}{lllll}\text { Journal of Islam and Muslim } & \text { Societies, } & 9(1), & \end{array}$ https://doi.org/10.18326/ijims.v9i1.135-162

Farah, J. M. S., Shafiai, M. H. B. M., \& Ismail, A. G. B. (2019). Compliance behaviour on zakat donation: A qualitative approach. IOP Conference Series: Materials Science and Engineering, 572(1). https://doi.org/10.1088/1757-899X/572/1/012040 


\section{Macrothink}

Journal of Public Administration and Governance ISSN 2161-7104 2022, Vol. 12, No. 1

Farrell, A. M., \& Rudd, J. M. (2009, January). Factor analysis and discriminant validity: A brief review of some practical issues. Australia-New Zealand Marketing Academy Conference, New Zealand.

Fauziati, P., Minovia, A. F., Muslim, R. Y., \& Nasrah, R. (2016). The impact of tax knowledge on tax compliance case study. Journal of Advanced Research in Business and Management Studies, 2(1), 22-30.

Ghozali, I. \& Latan, H. (2015). Konsep, Teknik, Aplikasi Menggunakan Smart PLS 3.0 Untuk Penelitian Empiris. Semarang: BP Undip.

Henseler, J., Ringle, C. M., \& Sarstedt, M. (2014). A new criterion for assessing discriminant validity in variance-based structural equation modeling. Journal of the Academy of Marketing Science, 43(1), 115-135. https://doi.org/10.1007/s11747-014-0403-8

Juliansyah Noor (2017). Metodologi penelitian, skripsi, tesis, disertasi, \& karya ilmiah Jakarta: Kencana Media Group.

Kassim, S., Abdullah Othman, A. H., \& Haron, R. (2021). Handbook of Research on Islamic Social Finance and Economic Recovery After a Global Health Crisis. Hershey: Business Science Reference.

Ma'fiyah, M., Yughi, S. A., \& Awaludin, T. (2018). Preferensi muzakki dalam memilih membayar zakat di lembaga zakat formal. AL-FALAH: Journal of Islamic Economics. https://doi.org/10.29240/alfalah.v3i2.535

McKinsey Global Institute (2012, September 1). The archipelago economy: Unleashing Indonesia's potential. Retrieved from https://www.mckinsey.com/featured-insights/asia-pacific/the-archipelago-economy]

Memon, A. H., \& Rahman, I. A. (2014). SEM-PLS analysis of inhibiting factors of cost performance for large construction projects in Malaysia: Perspective of clients and consultants. The Scientific World Journal, 2014. https://doi.org/10.1155/2014/165158

Nurhayati, S., \& Siswantoro, D. (2015). Factors on zakat (tithe) preference as a tax reduction in Aceh, Indonesia. International Journal of Nusantara Islam, 03(01), 1-20.

Palil, R. M. (2005). Taxpayers knowledge: A descriptive evidence on demographic factors in Malaysia. Jurnal Akuntansi Dan Keuangan, 7(1), 11-21. https://doi.org/10.9744/jak.7.1.pp.11-21

Puskas BAZNAS. (2020). Outlook Zakat Indonesia 2020. In Baznas. https://puskasbaznas.com/publications/books/1418-outlook-zakat-indonesia-2021.

Razimi, M. S. A., Romle, A. R. \& Erdris, M. F. M. (2016). Zakat management in Malaysia: A review. American-Eurasian Journal of Scientific Research, 11(6), 453-457. https://doi.org/10.5829/idosi.aejsr.2016.453.457

Roni, S. M., Djajadikerta, H., \& Ahmad, M. A. N. (2015). PLS-SEM approach to second-order factor of deviant behaviour: Constructing perceived behavioural control. 
Procedia $\quad$ Economics 2022, Vol. 12, No. 1

https://doi.org/10.1016/s2212-5671(15)01107-7

Saad, A. Y. Q., \& Foori, A. M. Al. (2020). Zakat and tax: A comparative study in Malaysia. International Journal of Innovation, Creativity and Change, 10(12), 140-151.

Sani Adamu, M., \& Ram Al Jaffri, S. (2016). Determinants of trust on zakat institutions and its dimensions on intention to pay zakat: A pilot study. Journal of Advanced Research in Business and Management Studies, 3(1), 40-46.

Taha, R., Adam, F., Ali, N. N. M., \& Ariff, A. M. (2017). Religiosity and transparency in the management of zakat institutions. Journal of Legal, Ethical and Regulatory Issues.

The World Bank (2021, 30 March). Population - total. Retrieved from https://data.worldbank.org/indicator/SP.POP.TOTL?locations=ID

The World Bank (2020, January 30). Expanding Middle Class Key for Indonesia’s Future.

Retrieved from

https://www.worldbank.org/en/news/press-release/2020/01/30/expanding-middle-class-key-fo r-indonesia-future

Zainal, H., Bakar, A. A., \& Saad, R. A. J. (2016). Reputation, satisfaction of zakat distribution, and service quality as determinant of stakeholder trust in zakat institutions. International Journal of Economics and Financial Issues, 6(7S), 72-76.

\section{Copyright Disclaimer}

Copyright for this article is retained by the author(s), with first publication rights granted to the journal.

This is an open-access article distributed under the terms and conditions of the Creative Commons Attribution license (http://creativecommons.org/licenses/by/4.0/). 